\title{
nature
}

28 April 2005 Volume 434 Issue no 7037

\section{Dealing with design}

The idea of intelligent design is being promoted in schools and universities in the United States and Europe. Rather than ignoring it, scientists need to understand its appeal and help students recognize the alternatives.

$\mathrm{S}$ cientists tend to tune out when they hear the words 'intelligent design'. The concept, which endeavours to show God's hand shaping the course of evolution, is being promoted in parts of Europe and, more significantly, has recently become popular among Christian fundamentalists who want religion taught in US secondary schools. To most researchers it sounds like politics rather than science, and like someone else's problem.

Mixing as it does the supernatural with scientific doctrine, the concept is a throwback to the days when natural philosophers pursued pseudoscientific disciplines such as alchemy. But the scientific community should not ignore it. As the article on page 1062 reveals, the concept is gaining popularity on US college campuses.

That is because many of the students taught in introductory biology classes hold religious beliefs that conflict, at least on the face of things, with Darwin's framework. Professors rarely address the conflicts between faith and science in lectures, and students are drawn to intelligent design as a way of reconciling their beliefs with their interest in science. In doing so, they are helping it to gain a small, but firm, foothold on campuses around the country.

This is bad news for researchers. Unlike 'creation science', which uses the Bible as its guide, intelligent design tries to use scientific methods to find evidence of God in nature. This approach makes it less theologically heavy-handed than its predecessor, but it also poses a threat to the very core of scientific reason. Most contemporary researchers believe that it is better to keep science and theology firmly separated. Most theologians would agree: intelligent design is not a part of Catholic doctrine, for example.

So what can scientists do to counter the appeal of intelligent design? The concept's advocates frequently approach researchers with offers of campus-wide 'Darwin versus design' debates. Such events tend to be well attended, but don't change many minds. Furthermore, ill-prepared scientific lectures can sometimes lack the superficial impact of design advocates' carefully crafted talking points.

Scientists know that natural selection can explain the awe-inspiring complexities of organisms, and should be prepared to explain how. But attacking or dismissing intelligent design is likely to aggravate the rift between science and faith that causes students to become interested in intelligent design in the first place.

Scientists would do better to offer some constructive thoughts of their own. For religious scientists, this may involve taking the time to talk to students about how they personally reconcile their beliefs with their research. Secular researchers should talk to others in order to understand how faiths have come to terms with science. All scientists whose classes are faced with such concerns should familiarize themselves with some basic arguments as to why evolution, cosmology and geology are not competing with religion. When they walk into the lecture hall, they should be prepared to talk about what science can and cannot do, and how it fits in with different religious beliefs.

Some will be troubled by the suggestion that they discuss these issues in the classroom. Indeed, it is not the job of a science teacher to meddle with the way their students are brought up or to attack their core personal beliefs. Rather, the goal should be to point to options other than intelligent design for reconciling science and belief.

Even if they manage to sway just a few students, researchers in the United States can have a disproportionate effect on the national debate over science in the classroom. Students often return to their home communities and become teachers, doctors and engineers. It is as local community leaders that those students will become invaluable allies when more conservative religious groups try to halt the teaching of scientific theories in schools.

\section{New accountability in China}

\section{A Chinese funding agency has a new constitution, supporting better selection. Will it spread?}

A new constitution implemented earlier this month by the National Natural Science Foundation of China (NSFC) shows a penchant for transparent and accountable governance. Those who drafted it say it will establish norms and a code of conduct to regulate the foundation's work in a democratic fashion, to establish management based on the law, and to ensure the effective use of funds. It is aimed, as senior NSFC policy-maker Liu Zuoyi put it, at "utilizing overseas brainpower and encouraging overseas scientists to participate in China's basic research" in a "rigorous way".

To draft the constitution, the NSFC studied about 20 legislative documents worldwide, such as the Australian Research Council Act. According to Liu, the constitution guarantees the fairness of funding opportunities by setting out "standards in selecting experts for peer and panel reviews" and "requirements for the management of programmes and results". Failure in such endeavours has been a long-standing complaint of scientists in China and those thinking of returning to the country.
This is all well and good, but the NSFC already has a reputation for fair funding. Scientists' main complaint with its grants has been that the money is too small to pack a punch. In 2004, it handed out 2.8 billion yuan (US $\$ 340$ million), a $25 \%$ rise over 2003 but still only $1.3 \%$ of China's total research and development spending. This money was spread over some 8,300 projects.

Nevertheless, this is a positive step that could make China seem a more comfortable place for the returning scientists on whom the country rests so much of its hopes. But the NSFC's constitution also points to deep problems in other parts of the Chinese funding system. Its impact depends on how well it can inspire other organizations in particular the Ministry of Science and Technology and the Chinese Academy of Sciences, which account for the lion's share of research funding and hence hold the corresponding responsibility for China's scientific future - to take steps to improve the fair and effective deployment of their money. Will such organizations take up the challenge and follow the NSFC's lead? 